\title{
Risk Prevention of P2P Online Loan Based on the Criteria of Selection of Commercial Bank Loan
}

\author{
Chenqi Jiang* \\ School of Economics and Management \\ Nanjing University of Science and Technology \\ Nanjing, China \\ 1446749163@qq.com
}

\author{
Caixia Zhou \\ School of Economics and Management \\ Nanjing University of Science and Technology \\ Nanjing, China \\ 1114241428@qq.com
}

\begin{abstract}
This paper empirically tests whether the traditional commercial bank lending selection criteria can help investors effectively reduce lending risk. Establishing Poisson and Logit regression models based on loan data of RenrenDai, the results show that although the borrower who provides proof information according to the commercial bank loan screening criteria makes the investor spend more time to judge, it significantly reduces the number of bidders required to complete the tender, and the probability of default is also lower. This reveals that the traditional commercial bank lending selection criteria still have good applicability in the network lending market, providing investors with an effective information review reference to accurately judge the situation of borrowers, lowering the investment risk as well.
\end{abstract}

Keywords-online peer-to-peer lending; commercial banks; investors; lending platforms

\section{INTRODUCTION}

Since 2018, runway incidents on P2P platform have occurred frequently. After choosing a platform with high reliability, investors need to choose reliable borrowers on the platform to decide whether to lend funds or not. With the strengthening of government supervision, the difficulty of risk identification of the platform will be further reduced, but the risk control of borrowers in the platform will always need to be handled by investors themselves. Different from the mode in the United States, the structure of P2P in China is a large number of individual investors responding to a large number of individual borrowers. Information asymmetry exists in the traditional commercial bank lending business and the emerging Internet finance. Borrowers are always in the dominant position. Besides of interest rate and lending period, the completion of loan depends largely on investors' judgment on borrowers' repayment ability and credit status. Commercial banks, as traditional financing intermediaries, have established a set of relatively perfect and effective criteria for loan selection. Thus, whether investors can use this logic system for reference has become topic in this paper.

At present, there are various studies on the information of online borrowers. Previous studies have found that borrowers' age, appearance, gender [1], professional status [2], social capital, credit rating [3] have strong transmission effects. In the aspect of risk prevention of P2P lending, most of the existing

Jiangsu University Philosophy and Social Science Research Project (2017SJB0027); supported by "the Fundamental Research Funds for the Central Universities”, No. 30918013133 studies focus on the risk evaluation of online lending platform $[4,5,6]$. Although the theoretical research on online lending is getting deeper, the domestic online lending market is still not as effective as the weak market. Investors are far from fully rational [7]. Therefore, it is still important to help investors improve decision-making efficiency and reduce risk through information research on borrowers.

Based on the actual operation mode of China's P2P online lending platform business, this paper puts forward the hypothesis to be verified in connection with similar loan projects of commercial banks, and establishes an empirical model based on 20823 loan data extracted from Renrendai Platform. The results of empirical test show that the traditional selection criteria for commercial banks' lending have good applicability in the network lending market, and can provide information audit reference for investors, so that they can more accurately judge the situation of borrowers, thereby reducing investment risk.

\section{EMPIRICAL ANALYSIS}

\section{A. Hypothesis}

In the network P2P lending market, investors need to evaluate borrowers' repayment willingness and repayment ability in a number of borrowing targets, and select borrowers who meet their own requirements. When a large number of borrowers and investors with different maturities and financial needs gather in an individual network lending platform, without guaranteed repayment, and investors are at their own risk, if the platform cannot take effective collection mechanism for defaulting borrowers, due to information asymmetry and other factors, only borrowers with single-term borrowing needs will have the motivation to default or not to repay their loans. For borrowers with multi-period capital needs, they are more likely to choose to build a good reputation. Reputation status affects investors' judgment on borrowers' credit status, and then determines borrowers' borrowing results. On the other hand, a good reputation requires borrowers to pass on qualifications to investors. In other words, the final utility level of multi-period borrowers is closely related to the default probability deduced by investors based on borrowers' information. The results also theoretically emphasize the importance of the quality of information disclosure of borrowers and the importance of prescreening the credit status of borrowers by investors. 
For single-term borrowers, if the platform can introduce an effective collection and punishment mechanism, it can form a deterrent effect in theory. In the face of strong penalties, dishonest borrowers not only have to repay their loans, but also pay an extra heavy price. Therefore, rational borrowers, whether in single or multi-term borrowing, will choose to pay back the money. However, considering the difference between the cost of collection and the actual situation of borrowers, whether the platform punishment mechanism is really deterrent in practice needs to be questioned. This objective reality also makes it necessary for investors to consider carefully the credentials of borrowers when bidding, even if there is a punishment mechanism, so as to reduce the investment risk as much as possible.

Considering the difficulty of directly observing the criteria of investors' lending, we investigate investors' lending preferences from the time of completing a loan and the number of lenders. Disclosure information of borrowers in online lending is similar to that of commercial banks. Accordingly, hypothesis 1 to be verified is proposed.

H1: In P2P lending, the commercial banks' loan selection criteria have good applicability, that is, the time required to complete the bidding under this information standard is reduced, and the number of people required is also reduced.
On the other hand, compared with the final capital income, whether the lent funds can be repaid is the first point for investors to consider. This means that the default rate of borrowers directly affects investment risk. Therefore, hypothesis 2 to be verified can be proposed:

H2: In P2P lending, commercial banks' loan selection criteria provide investors with information audit model to reduce investment risk, that is, the borrower who meets the criteria has a lower probability of default.

\section{B. Model}

The data in this paper are selected from $t$ Renrendai. Considering that P2P industry has entered the stage of substantial rectification in 2018, and the investment mood fluctuates greatly, the data of repayment from January 1 to December 31, 2017 are randomly selected. After preliminary screening and eliminating the missing values, a total of 20823 items were obtained, including 4152 credit orders issued in 2014, 5893 in 2015, 7503 in 2016 and 3275 in 2017. Among them, there are 1546 default orders

Combining theoretical analysis and research hypothesis, the following variables are selected:

TABLE I. DEFINITION AND DESCRIPTION OF VARIABLES

\begin{tabular}{|c|c|}
\hline Variables & Definition $\quad$ r \\
\hline Time & $\begin{array}{c}\text { The time spent on the completion of the borrowing target. Considering the possible impact of borrowing scale, the full bidding time here is } \\
\text { the real full bidding time (seconds)/borrowing scale (10,000 Yuan); }\end{array}$ \\
\hline Rate & The interest rate of a loan; \\
\hline Default & $\begin{array}{c}\text { In this paper, overdue, advance payment and breach of contract are treated as breach of contract. The default target value is } 0 \text { and the } \\
\text { normal repayment value is } 1 ;\end{array}$ \\
\hline Bids & $\begin{array}{l}\text { In order to eliminate the influence of time and amount, the dependent variable is measured by (the number of bidders per borrowing/the } \\
\text { duration of borrowing)/the amount of borrowing }(10,000) \text { when the tender is completed or the total number of people applying for lending } \\
\text { after the expiration of the tender period is stipulated; }\end{array}$ \\
\hline Lterm & The borrowing period is monthly and the minimum value is 1 ; \\
\hline Lmoney & The value of borrowing amount after natural logarithm; \\
\hline Gender & If the borrower's sex is male, it is 1 , and vice versa, it is 0. \\
\hline Age & Borrower's age; \\
\hline Marry & If the borrower's marital status is married, divorced or widowed, take 1 , and if he is unmarried, take 0 ; \\
\hline Income & $\begin{array}{l}\text { If the monthly income of the borrower is not disclosed, the value is 1; if the monthly income is below } 1000 \text { Yuan, take 2,1000-2000 Yuan } \\
\text { and 3,2000-5000 Yuan and 4,5000-10000 Yuan and 5,10000-20000 Yuan and 6,20000-50000 Yuan and above 7,50000 Yuan and } 8 \text { Yuan. }\end{array}$ \\
\hline Worktime & $\begin{array}{l}\text { If the length of service of the borrower is not disclosed, the value is } 1 \text {; when the length of service is less than } 1 \text { (including) years, } 2 \text { is taken } \\
\text { in 1-3 (including) years, } 3-5 \text { (including) years, } 4 \text { is taken in } 3-5 \text { (including) years, and } 5 \text { is taken in more than } 5 \text { years; }\end{array}$ \\
\hline Edu & $\begin{array}{l}\text { If the borrower's educational background is not disclosed, the value is } 1 \text {; if the borrower obtains a high school or lower education, the value } \\
\text { is } 2 \text {; if he obtains a college education, the value is 3; if he obtains a bachelor's degree, the value is } 4 \text {; if he obtains a graduate student or } \\
\text { above, the value is 5; }\end{array}$ \\
\hline House & Whether the borrower's real estate is available or not, take 1 if there is, and vice versa, 0. \\
\hline Car & Whether the borrower has a car or not, if so, it is 1 , and vice versa, it is 0 . \\
\hline HouseD & Whether the borrower has a mortgage or not, if so, it is 0 , and vice versa, it is 1 ; \\
\hline CarD & Whether the borrower wants car loan or not, if so, it is 0 , and vice versa, it is 1 ; \\
\hline Household_register & The certificate of the borrower's household register or place of residence, if any, takes the value of 1 , and vice versa, 0 ; \\
\hline Credit_cert & If the borrower's credit report has the certificate, the value is 1 , and vice versa, 0. \\
\hline CG & $\begin{array}{l}\text { According to the Credit Rating Table of Renrendai, when the borrower's credit rating is HR, it is } 1, \mathrm{E} \text { is } 2, \mathrm{D} \text { is } 3, \mathrm{C} \text { is } 4, \mathrm{~B} \text { is } 5, \mathrm{~A} \text { is } 6 \text {, AA } \\
\text { is } 7 .\end{array}$ \\
\hline PR_L & $\begin{array}{c}\text { The borrower's historical borrowing and repayment status in Renrendai, when at least one loan has been repaid or has not been borrowed on } \\
\text { the platform, takes the value of } 1 \text {, and vice versa, takes the value of } 0 .\end{array}$ \\
\hline Num_vc & The total number of certificates displayed by the borrower; \\
\hline
\end{tabular}

In order to test hypothesis 1, combining the general application conditions of commercial banks, the following models are constructed on the basis of existing literature research. 
Time $=\beta 0+\beta 1$ Rate $+\beta 2$ Lterm $+\beta 3$ Lmoney $+\beta 4$ Gender

$+\beta 5$ Age $+\beta 6$ Marry $+\beta 7$ Income

$+\beta 8$ Worktime $+\beta 9$ Edu $+\beta 10$ House

$+\beta 11$ Car $+\beta 12$ HouseD $+\beta 13$ CarD

$+\beta 14$ Household_register

$+\beta 15$ Credit_cert $+\beta 16 C G+\beta 17$ PR_L

$+\beta 18$ Num_vc $_{-}+\varepsilon$

Bids $=\beta 0+\beta 1$ Rate $+\beta 2$ Lterm $+\beta 3$ Lmoney $+\beta 4$ Gender

$+\beta 5$ Age $+\beta 6$ Marry $+\beta$ 7Income

$+\beta 8$ Worktime $+\beta 9$ Edu $+\beta 10$ House

$+\beta 11$ Car $+\beta 12$ HouseD $+\beta 13$ CarD

$+\beta 14$ Household_register

$+\beta 15$ Credit_cert $+\beta 16 C G+\beta 17$ PR_L

$+\beta 18$ Num_vc $+\varepsilon$

Model (1) uses Poisson regression and model (2) uses Poisson regression method.

To explore the correlation between information disclosure and default probability of borrowers, the following regression model is established.

$\operatorname{Pr}($ default $)$

$=\mathrm{f}$ (Rate, Lterm, Lmoney, Gender, Age, Marry, Income,

Worktime, Edu, House, Car, HouseD, CarD, Household_register,

Credit_cert, CG, PR_L, Num_vc) $+\varepsilon$

Model (3) uses Logit regression

\section{Descriptive Statistics}

TABLE II. VARIABLE DESCRIPTIVE STATISTICS

\begin{tabular}{|c|c|c|c|c|}
\hline Variables & $\begin{array}{c}\text { Maximum } \\
\text { value }\end{array}$ & $\begin{array}{c}\text { Minimum } \\
\text { value }\end{array}$ & $\begin{array}{c}\text { Average } \\
\text { value }\end{array}$ & $\begin{array}{c}\text { Standard } \\
\text { error }\end{array}$ \\
\hline Time & 0 & 49736 & 158.26 & 1071.84 \\
\hline Rate & .08 & .24 & 0.11 & 0.01 \\
\hline Default & 0 & 1 & 0.93 & 0.26 \\
\hline Bids & 0 & 117000 & 1249.83 & 3863.59 \\
\hline Lterm & 3 & 48 & 29.47 & 9.74 \\
\hline Lmoney & 6.91 & 12.98 & 10.70 & 0.88 \\
\hline Gender & 0 & 1 & 0.73 & 0.45 \\
\hline Age & 19 & 64 & 37.16 & 8.40 \\
\hline Marry & 0 & 1 & 0.74 & 0.44 \\
\hline Income & 1 & 8 & 5.05 & 1.38 \\
\hline Worktime & 1 & 5 & 3.09 & 1.23 \\
\hline Edu & 1 & 5 & 3.16 & 0.78 \\
\hline House & 0 & 1 & 0.55 & 0.50 \\
\hline HouseD & 0 & 1 & 0.64 & 0.48 \\
\hline Car & 0 & 1 & 0.22 & 0.41 \\
\hline CarD & 0 & 1 & 0.94 & 0.24 \\
\hline Household- & 0 & 1 & 0.01 & 0.11 \\
\hline register & 0 & 1 & 0.76 & 0.43 \\
\hline Credit_cert & 0 & 7 & 5.40 & 1.48 \\
\hline CG & 1 & 1 & 0.89 & 0.31 \\
\hline PR_L & 0 & 15 & 5.28 & 1.58 \\
\hline Num_vc & 2 & & & \\
\hline Dur & & 1 & 16 & 0.04 \\
\hline
\end{tabular}

Random sampling data show that the borrowers are mostly male, and most of them are unable to provide household registration books or residence certificates. On average, $55 \%$ of borrowers have real estate, only $22 \%$ have car property, and the average credit rating is about $\mathrm{B}$. The number of certificates they can provide is less than 6 .

\section{EMPIRICAL ANALYSIS RESULTS}

The following table describes the regression results of model (1), model (2) and model (3).

TABLE III. REGRESSION RESULTS OF LOAN INFORMATION ON THE TIME, BIDDERS AND DEFAULT

\begin{tabular}{|c|c|c|c|c|}
\hline & Variables & Time & Bids & Default \\
\hline \multirow{3}{*}{$\begin{array}{c}\text { General } \\
\text { information }\end{array}$} & Rate & $44.4350 * * *$ & $68.9378 * * *$ & -4.6816 \\
\hline & Lterm & $-0.0138 * * *$ & $-0.0473 * * *$ & $0.0596 * * *$ \\
\hline & Lmoney & $-0.2952 * * *$ & $-0.7457 * * *$ & 0.1345 \\
\hline \multirow{6}{*}{$\begin{array}{l}\text { Nature of } \\
\text { borrowers }\end{array}$} & Gender & $0.0490 * * *$ & $0.0067 * * *$ & -0.2717 \\
\hline & Age & $-0.0055^{* * *}$ & $0.0003 * * *$ & -0.0120 \\
\hline & Marry & $0.4380 * * *$ & $0.0004^{* *}$ & -0.0981 \\
\hline & Income & $0.17409 * * *$ & $-0.00012^{* *}$ & $\begin{array}{c}- \\
0.3714 * * *\end{array}$ \\
\hline & Worktime & $-0.1819 * * *$ & $-0.0038 * * *$ & -0.0362 \\
\hline & Edu & $0.0766 * * *$ & $0.0427 * * *$ & $0.5144 * * *$ \\
\hline \multirow{4}{*}{$\begin{array}{l}\text { Value of } \\
\text { borrowers }\end{array}$} & House & $-0.2184 * * *$ & $-0.2280 * * *$ & 0.0883 \\
\hline & HouseD & $-0.1794 * * *$ & $0.3066 * * *$ & -0.2335 \\
\hline & Car & $-0.2648 * * *$ & $-0.0279 * * *$ & 0.1473 \\
\hline & CarD & $-0.1221^{* * *}$ & $-0.0249 * * *$ & $0.5890 * *$ \\
\hline \multirow{7}{*}{$\begin{array}{c}\text { Risk of } \\
\text { borrowers }\end{array}$} & $\begin{array}{l}\text { Household- } \\
\text { register }\end{array}$ & $-0.1465 * * *$ & $0.0900 * * *$ & -0.1153 \\
\hline & Credit_cert & $1.1612 * * *$ & $0.7009 * * *$ & -0.2577 \\
\hline & CG & $0.2504 * * *$ & $1.2762 * * *$ & $2.6514 * * *$ \\
\hline & PR_L & $-0.4531^{* * *}$ & $-0.0944 * * *$ & - \\
\hline & Num_vc & $0.1153 * * *$ & $-0.2913^{* * *}$ & $\stackrel{-}{-} 0.0886^{* * *}$ \\
\hline & $\mathrm{C}$ & $0.7207^{* *}$ & $1.4287 * * *$ & $\begin{array}{c}- \\
5.6922 * * * \\
\end{array}$ \\
\hline & Pseudo R2 & 0.0824 & 0.3090 & 0.8446 \\
\hline
\end{tabular}

The regression results of model (1) show that investors pay more attention to the borrower's housing/car, job qualifications and age. Such indicators can significantly reduce the time of full bidding. In the borrower's risk information, the past borrowing situation and the household register or residence certificate can help borrowers effectively convey their own quality, but the disclosure of credit reporting and credit rating is negatively correlated at the level of $1 \%$.

Borrowers' value, i.e. their asset status, can significantly reduce the time of full bidding. However, in online lending, borrowers' risk information and the number of certifications overturn traditional perceptions: the higher the credit score, the more the number of certifications, the longer it takes for borrowers to complete the bidding. At the same time, compared with the intuitive number of certification, the detailed description of the borrower's value and risk information has a greater impact on the full bidding time. The possible reason is that high-quality borrowers in online lending often need multiple indicators to verify support, which makes investors spend more time to judge whether the quality of information is high or low.

In the model (2), the selection information of commercial bank loans has a significant impact on the number of bidders required to complete the bid. Interestingly, in judging the value of platform credit rating, investors have cognitive bias. The higher the credit rating, the more investors need to complete the target amount. Investors seem to rely more on their own ability to make judgments from borrowers' information than 
using platform ratings as a discriminant reference. The results also show that investors lack trust in the platform.

After eliminating the disturbance variables, the regression of model (3) is obtained. The results show that the borrower's demographic, social relations, self-worth and risk information can better predict the borrower's default situation according to the label information of the commercial bank's "portrait" of customers. However, the significant negative relationship between the number of certification and default probability indicates that borrowers may use some soft information to confuse investors' audiovisual information in online lending, so as to improve their credibility. Therefore, commercial bank loan information can help investors to predict the quality of borrowers to a certain extent, but it should pay more attention to some hard indicators, such as credit rating, education and so on, when bidding.

\section{CONCLUSIONS AND SUGGESTIONS}

The empirical results show that in the P2P lending, the criterion of commercial bank loan selection has good applicability, and it also provides an information audit model for investors. The information provided according to the commercial banks' criterion can effectively judge the borrower's situation.

However, it is worth noting that compared with the platform rating, investors tend to believe in their own evaluation of the borrower's credit status, but this may be "overconfidence". The regression results show that borrowers can "smartly" counter-detect investors' preferences, and use this preference to "decorate" themselves to gain trust. Therefore, investors should give more weight to hard indicators such as academic qualifications and platform ratings when making decisions. However, in the actual bidding process, investors have various cognitive biases, which deserve more in-depth discussion and research. This also reflects to a certain extent that the frequently occurring problem platform makes investors skeptical about the professionalism of the lending platform.

The P2P platform should be a financial information intermediary company that provides information collection, information publication, credit evaluation, information exchange and loan matching services for borrowers and lenders through the Internet as the main channel. A large number of platforms in the market are different from or even contrary to this positioning, which makes investors need to screen the platform before they can identify the quality of borrowers. Even when they choose borrowers, they can't trustingly use the information of the platform for reference, which further reduces the investment efficiency. In this regard, we suggest that the network P2P lending platform should first clarify the identity of its own information intermediaries and mandatory third-party trusteeship of funds; secondly, improve the level of risk management, reduce the overall default rate of the platform, and introduce effective penalty mechanisms, including collection of overdue accounts, access to the central bank credit collection system, etc., to improve the credit threshold of borrowers; finally, it is suggested that the network lending platform can strengthen the study of traditional commercial banks 'related business, so as to promote the healthy development of their own business and become a useful supplement to formal finance.

\section{ACKNOWLEDGMENT}

R. B. G. thanks for the financial support of Nanjing University of Science and Technology, as well as my mentor, Professor Zhou, for her thoughtful guidance and care. Without their help, the paper might not have been formed..

\section{REFERENCES}

[1] J Duarte, S Siegel, and L Young, "Trust and credit: the role of appearance in peer-to-peer lending,” The Review of Financial Studies. vol. 25, pp. 2455-2484, August 2012.

[2] X.J. Tian, and Z.Y Zhang, "Credit discrimination on occupational identity in P2P lending: based on the perspective of investor's cognitive bias,” Reform, pp. 139-150,May 2018.(In Chinese)

[3] H.J. Wang, and L. Li, "Chinese P2P platform's credit authentication mechanism research-evidence from Renrendai,” Chinese Industrial Economics, pp. 136-147, April 2014. (In Chinese)

[4] H. Liu, and G.L. Yan, "Research on platform preference risk of P2P online lending investors,” Journal of Finance and Economics, 2018, pp. 26-32. (In Chinese)

[5] Y.L. Shi, B.J. Zhang, and H. Jiang, "Research on screening risk of P2P online lending platform,” Statistics and Decision, 2018, pp. 153-156. (In Chinese)

[6] C.Y. Xie, and M.B. Han, "Research on risk assessment of P2P platform in China based on AHP,” J. North China University of Technology, vol. 30, pp. 116-120, February 2018. (In Chinese)

[7] Y. Chen, "Empirical study on the market effectiveness of China's P2P network lending market,” Reform of Economic System, 2018, pp. 137144. (In Chinese) 